
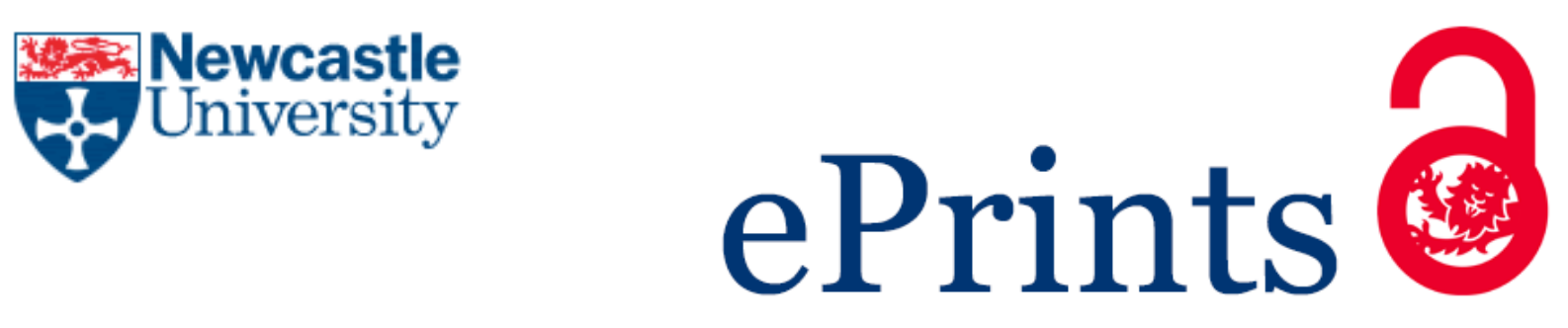

Lain D, Loretto W. Managing Employees Beyond Age 65: From the Margins to the Mainstream?. Employee Relations 2017, 38(5), 646-664.

\title{
Copyright:
}

(C) 2016 Emerald Publishing Limited.

DOI link to article:

https://doi.org/10.1108/ER-04-2015-0062

Date deposited:

$19 / 09 / 2017$

Embargo release date:

10 June 2018

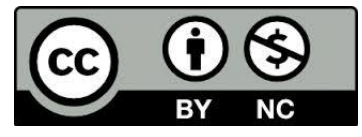

This work is licensed under a Creative Commons Attribution-NonCommercial 3.0 Unported License 


\section{Managing Employees Beyond Age 65: From the Margins to the Mainstream?}

Abstract Purpose: Against a backdrop of legislative and policy changes, this article assesses the extent to which the over-65 age-group is moving from the margins to the mainstream of UK employment. It aims to fill a gap in HR research and practice which, it is argued, has paid relatively little attention to the over-65s.

Design: The analysis draws on three waves of the Labour Force Survey (2001, 2008 and 2014), to explore the extent to which organisational, occupational and sectoral marginalisation of the over$65 \mathrm{~s}$ has changed in the 21st Century.

Findings: The results show that the share of 65-69 year olds working as employees doubled between 2001 and 2014, primarily because long-term established employees worked longer.

Overrepresentations of lower-level 'Lopaq' occupations reduced, and over-65s became more integrated across occupations and sectors.

Research implications: More research is needed to understand the factors driving the steady move from the margins to the mainstream (for example, LFS does not measure pensions), and future research on the older workforce should automatically include workers in this age-group.

Practical implications: The discussion considers the implications for managerial practice, in a context of increasingly age-diverse workforces.

Originality/Value: This article addresses a gap in research into later-life working and also demonstrates the ways in which the nature of employment among the over-65s is changing, thereby challenging some of the assumptions about those who work into later life and how they are - or should be- managed.

Paper type: Research paper

Keywords: working past 65; age-diversity, marginalisation, older workers 


\section{Introduction}

Economic pressures arising from population aging have put the policy spotlight firmly onto the older workforce, with the emphasis on extending working lives up to and beyond state pension ages. UK governments have used a range of measures to keep people in work longer, including raising state pension ages and abolishing mandatory retirement for most jobs. Such is the pace of change that HR research and practice are arguably lagging behind. The overwhelming focus is still on the older worker as someone aged between 50-64 who faces age discrimination and labour market marginalisation. Drawing on Labour Force Survey data, this article broadens the focus, providing an insight into the changing employment patterns of the over-65s in the UK since the early 2000s. It argues that in many ways this age-group is moving from the margins to the mainstream of the labour market. It then discusses the implications for managing a workforce that will increasingly include those aged over 65 , thereby contributing to the call by the HR profession for a more proactive approach to managing ageing and age diverse workforces (CIPD, 2014).

\section{The changing landscape for over-65s in the UK labour market}

Before the introduction of old age pensions a period of voluntary retirement was rare. Older people were often integrated into mainstream organisational life through workplace arrangements that moved them into 'light work' as they aged (Phillipson, 1982). However, with the advent of the 'modern organisation', employers and trade unions increasingly sought to arrange the routinised exit of older people via occupational pensions (Hannah, 1986). Retirement gained further dominance with the mass expansion of state pensions from 1948, for men aged 65 and women aged 60. Employment beyond 65 nevertheless remained common up to the mid-1960s, when around a quarter of men aged 65+ worked (Lain, 2011a). After this time male employment past age 65 slumped to around $7-8 \%$ by the mid-1980s where it remained until the early 2000 s. However, since 2000 the employment rates for over-65s have been rising, reaching their highest levels $(10.1 \%)$ since 1992 (ONS, 2013). The growing size of this age-group, and their increased likelihood of working, mean that the number of workers aged 65-plus is at record high of 1.1 million. While representing a relatively small proportion of the total population over over-65s, it is notable that this employment growth occurred through varying, often challenging, economic conditions. Historically, reduced labour market demand led to declines in employment over age 65 (Macnicol, 2006; Riach 2009), but this did not occur after the 2008 financial crash (Beck, 2013). One key change over the period has been the introduction of age discrimination legislation. The Employment (Age) Regulations 2006 outlawed unjustified discrimination on grounds of age, introduced a right for employees to request working beyond 65 and placed a duty on employers to consider such requests (Parry and Tyson, 
2009: 472). Research suggests that employers allowed continued employment beyond age 65 on a business-case basis (Flynn, 2010). In 2011, following a series of legal challenges, the default retirement age of 65 was abolished, effectively outlawing mandatory retirement unless the employer can provide a legally justifiable reason (see below). Moreover, even before the legislative changes, throughout the 2000s the 'business case' for employing older people was achieving more coverage, linked to debates about the benefits of organisational diversity (Lain, 2012; Loretto and White, 2006). There is reason to believe that recent increases in the employment of over-65s likely to become a long term trend. Following the example of the US, the abolition of default retirement should allow people to remain in the workforce for longer (Adams, 2004; Lain, 2012), while the financial need to continue working is set to increase with declining salary-related occupational pensions and rising ages for state pensions and means-tested Pension Credit (see Lain and Vickerstaff, 2015).

Despite the growth in employment, concerns remain about the potential marginalisation of older workers. Writing in the 1990s, Taylor and Walker (1994: 588) suggested that 'the labour market..[may] become increasingly age-segmented with available employment for older workers generally consisting of low-skill, low-responsibility and low-paid work with fewer opportunities for career advancement'. Lain (2012) confirmed that employees beyond 65 in the early 2000s were disproportionately in 'Lopaq' occupations, that were typically low paid, part-time, required few formally recognised skills, and were unattractive to the 'core-age' workforce. Standing (2011) expressed concern that older workers are being pushed into the 'precariat', by taking jobs lacking employment security (protection from arbitrary or unreasonable dismissal), job security (a defined occupational niche that can be advanced further), and income security (an adequate stable income).

Standing's position, which is not based on an empirical analysis, implicitly assumes that over-65s will be forced to retire from their career jobs. It is likely that the abolition of default retirement age in 2011 has substantially removed such involuntary moves. In the early 2000s around half of employees worked in establishments with mandatory retirement ages, most at 65 or below (Metcalf and Meadows, 2006: 65). More recent evidence (CBI, 2013), in contrast, suggests only a minority (5\%) of employers have retained a compulsory retirement age, via an 'employer justified retirement age' (EJRA). However, this does not mean an end to the potential marginalisation of the over-65s workforce. The EJRA permits an employer to set a retirement age where it represents a 'proportionate means of achieving a legitimate aim'. Coleman (2011) indicated that a substantial majority of employers (25\%) would like a retirement age, with concern over high youth unemployment being voiced as one of the key motivators, while the $\mathrm{CBI}$ survey cited above found 
that a further third of employers said they 'needed' to use compulsory retirement ages but felt unable to use them due to risk and uncertainty. This 'organisational ambivalence' towards over-65s may still reflect ageist assumptions and age stereotyping, but it is also likely to be a symptom of the lack of confidence, knowledge and experience in managing a 'new' group of people within a changing demographic, pensions and legal context.

\section{Managing the over-65s: a marginal activity?}

In fact, the whole issue of managing the over-65s workforce could be considered a fairly marginal activity to date. This position is reflected in academic research which reveals a disconnect between focusing on the individual versus organisational and management concerns. Most UK research on the employment of over-65s has focused on the individual - assessing the motivations and characteristics of those in work. Factors such as orientation to work (Parry and Taylor, 2007), health (Lain 2011b; Griffin and Hesketh, 2008), educational qualifications (Smeaton and McKay, 2003; Lain, 2011a), gender / domestic situations and responsibilities (Loretto and Vickerstaff, 2013) and financial circumstances (McMunn et al, 2009) affect individual preferences and decisions. In contrast, employment and organisational policies have been driven by official and popular conceptions of the 'older worker', most often considered to be someone aged between 50 and SPA. Likewise, much of the HR literature has tacitly assumed older workers to be those aged up to 65 . As an illustration, Armstrong-Stassen's (2008) examination of post-retirement employment identified the importance of the HR policies and practises in terms of recruiting people over age 50 that had retired; however, this analysis excluded those over age 65. Work in the Netherlands (Bal et al, 2012), on the other hand, exploring the desire to work over statutory retirement age contained very few that were even older than 60 . Concerns over age discrimination and the barriers posed to recruiting and retaining over-50s have dominated HR debates in the 1990s and early 2000s (for a review, see Wood et al, 2008), with relatively little attention being paid to proactively managing those remaining in employment beyond traditional age of retirement. As a result, the changes to the over-65s workforce outlined above are not yet adequately reflected in HR research and debates.

Thus, in summary, there has been a lack of academic analysis on the extent to which the growth in employment of the over-65s in the 21st Century represents a return to the mainstream from the margins of employment. This empirical investigation aims to address this gap, and to explore the HR consequences. Marginalisation/integration is examined empirically in relation to three dimensions. First we examine 'organisational marginalisation/integration', which we frame in terms of the following hypotheses: 
- Hypothesis 1: Workers beyond age 65 are becoming more organisationally integrated as employees with long term employment relationships and open ended contracts.

In the past the weak employment rights of this age group meant that there were fewer opportunities for employees to continue working beyond age 65 (Vickerstaff, 2006). Employer casestudy research covering the early 2000s found that line managers were important in deciding whether an employee would be allowed to continue working beyond the 'normal' employer pension age (Vickerstaff et al 2003; Vickerstafff et al., 2004: Vickerstaff 2006a; Vickerstaff 2006b). Most employees interviewed felt they had little realistic opportunity to work past age 65 . Other research furthermore suggests that around half of UK employees had a mandatory retirement age in their employment contract at this time (Metcalfe and Meadows, 2006). However, a lack of employment rights for all employees over age 65 meant that line-managers/employers could constrain opportunities to work at age 65-plus (Lain and Vickerstaff, 2015). As a result, employment at 65-plus was to a greater degree confined to the self-employed, because they did not face the same organisational constraints on working experienced by employees (Smeaton and McKay, 2003). When people did work as employees beyond age 65 they were more likely than today to be in recently acquired jobs or temporary employment. Smeaton and McKay (2003) found that workers over state pension age were disproportionately on temporary contracts (relative to younger groups). Likewise, Lain (2012) found that just under half employees aged 65-69 in the early 2000s had started their job in their sixties. This is likely to be partly because many individuals wanting to work had to find new jobs if they were forced to retire from their previous employment. With the abolition of mandatory retirement ages we would expect workers aged 65-plus to be more integrated into work as permanent long-term employees. Consistent with this, research suggests that US age discrimination legislation increased the retention of older workers (Neumark, 2009; Lain and Vickerstaff, 2015). In contrast with this, however, the logic of Standing's arguments (2011) instead suggests that over UK 65 s may instead be re-joining the work-force by taking new precarious jobs.

The second measure of marginalisation/integration relates to the hours of work people aged 65-plus do; this is expressed in the following hypothesis:

- Hypothesis 2: Workers aged 65-plus are becoming more integrated into full-time employment.

Employment beyond State Pension Age has, in the past, been to a considerable degree been part-time (Smeaton and McKay, 2003). This is likely to partly reflect the fact that when individuals reached 65 they had they had to make a case for working beyond 65 . In this negotiation process we might expect options such as a reduction in hours to be discussed, something that is popular with many older people 
(Vickerstaff, 2007). With the abolition of mandatory retirement working past 65 is likely to be a more automatic process, so we might expect full-timers working a bit beyond their $65^{\text {th }}$ birthday to continue working their previous hours. This is likely to result in a reduction in the concentration of part-time work among people working past 65.

The final hypothesis relates to occupational/sectoral marginalisation:

- Hypothesis 3: Employees over age 65 are becoming less marginalised in a narrow range of occupations and sectors?

As noted above, in the past employees over 65 were disproportionately retained and recruited to 'Lopaq' jobs (Lain, 2012). Lopaq jobs had high rates of part-time work, along with low weekly wages and low qualifications (a proxy for the low formally recognised skill requirements). These jobs include shop sales persons and cashiers, waiters, bar tenders, food preparers, cleaners, domestic helpers, personal healthcare workers ('home help'), and care-takers among others. Now individuals across occupational groups have the option to continue working beyond 65 we would expect the occupational spread of employees to widen (Lain, 2012). Likewise, in the past employees over 65 were disproportionately in sectors with lots of Lopaq-or-similar-jobs, such as retail and hospitality (Lain, 2009). In contrast, in sectors such as Public Administration and Defence compulsory retirement ages at or below 65 were common (Metcalf and Meadows, 2006: 74). We would therefore expect any under-representation of employees aged 65-plus to be reduced in sectors such as these. In sum, with the abolition of mandatory retirement we might expect workers beyond age 65 to be more 'organisationally integrated' into employment as employees, and less marginalised in a narrow range of occupations/sectors. On the other hand, the arguments of Standing (2011) suggest a marginalisation of over 65s into newly acquired low-level jobs. The consequences for managing workers aged 65 and over will depend upon whether they are long-term employees spanning a range of occupations and sectors, or recent recruits marginalised into precarious jobs. An empirical examination is therefore required.

\section{Data and Methods}

The analysis here considers those aged 65-69, the sub-group of over 65 s most likely to work (Smeaton and McKay, 2003), at three points in time: 2001; 2008 (after the right to request continued employment beyond 65 but before the effects of the financial crisis); and 2014, when the economy was coming out of recession and after the abolition of mandatory retirement. 
The Labour Force Survey (LFS) has been selected for this analysis (July to September files). The samples used are large, ranging from 5964 to 6464 in the period covered, and contain 450 employees aged 65-69 in 2001, 658 in 2008, and 858 in 2013. This overcomes a key problem found in other surveys of small samples of employees over 65 (Lain, 2012). Organisational integration/segregation (Hypothesis 1 ) is assessed using variables on employment status (whether an employee or self-employed), employment contract (temporary/permanent) and length of time with the current employer. Integration into full time work (Hypothesis 2 ) is measured using the individual's categorisation of whether they are employed full or part-time; we also examine the voluntariness of part-time working (whether they would prefer full-time work). Organisational / Sectoral integration (Hypothesis 3) is assessed using the UK Standard Industrial Classification 1992 and the LFS occupational classification SOC 2000. Lopaq occupations were identified by recoding SOC 2000 to combine Personal Service, Sales/Customer Service, and Elementary occupations. Changes to occupational categorisations across the time period meant merging managers, professionals and associate professionals into a single category ${ }^{1}$. This prevents testing for employment differences between managers, who have firm-specific skills, and professionals with occupationally specific skills (Crompton, 2001). While unfortunate, this was necessary for comparability across the time periods.

A further limitation of the LFS is that is does not contain data on occupational pensions held by the individual. One might argue that increases in employment beyond age 65 purely reflect occupational pension changes; however, this is unlikely that this is the case in the UK thus far. Workers do increasingly have defined contribution (DC) pensions that will pay out potentially unpredictable lump sums. This is likely to encourage increased employment beyond age 65 in future, particularly if pension 'pots' decline significantly in the context of financial turmoil (Lain, forthcoming). In the US, where these pension changes occurred earlier, people with DC pensions retire later than those with more predictable salary-related Defined Benefit (DB) pensions (Munnell et al. 2004; Friedberg and Webb, 2005). However, this cannot be purely attributed to pensions - the ability of Americans to respond to financial incentives by working past age 65 is likely to have been influenced by the fact that mandatory retirement has long been abolished (Shultz, 1998). In the UK mandatory retirement was only abolished in 2011. In this context, analysis by Lain (forthcoming) found no evidence that people contributing to DC pensions in 2002 were more likely than those in DB schemes to work at age 65-74 in 2012. This is consistent with previous UK research suggesting that pension incentives

\footnotetext{
${ }^{1}$ The Soc 2010 occupational classification had replaced Soc 2000 for the 2014 survey. This resulted in some occupations moving between managerial, professional and associate professional categories, hence the need to merge these three occupational groups.
} 
have mainly influenced employment for men in their fifties (Banks et al. 2007). The growing importance of DC schemes is likely increase employment beyond age 65 in future, in a context in which mandatory retirement has been abolished. For the purposes of this paper, however, it is important to note that DB pensions were strongest in the public sector in this period. If pensions were the decisive factor influencing employment we would therefore expect limited employment increases in sectors such as Public Administration. The results below are discussed in light of this.

\section{Results}

\section{Working past 65: Organisationally integrated or marginal recruits?}

\section{TABLE 1 HERE}

Hypothesis 1 predicted that workers beyond age 65 were becoming more organisationally integrated as employees in long term jobs with open ended contracts. Table 1 shows that overall employment among the $65-69$ age group rose from $11.2 \%$ in 2001 to $16.3 \%$ in 2008 after the right to request continued employment, and to $20.2 \%$ in 2014 after the abolition of mandatory retirement. Self-employment rose over the period, but so did the percentages working as employees - from $7.5 \%$ in 2001 to $13.3 \%$ in 2014 . The numbers working as employees therefore remained modest, but had risen for men and women over a period that included the most severe recession in the post war period. Greater organisational integration is further reflected by a statistically significant decline of employees working under temporary contracts, from 18\% in 2001 to 11.5\% in 2014. Finally, Table 1 shows increased organisational integration in terms of over 65 s working as employees in long-held jobs. Figure 1 shows that the increase in employees aged 65-69 between 2008 and 2014 was entirely due to those in jobs lasting more than ten years working longer. In 2001 almost a half of employees had started their job in the last five years (45.2\%), falling to less than a quarter by 2014 (23\%). By 2014 , more than half of employees, 59\%, had been in their jobs for at least 10 years. Overall, therefore, consistent with Hypothesis 1, we do see greater organisational integration, with an increase in over 65 s working as employees in long-term jobs. This is in contrast to what we would expect given Standing's (2011) predictions regarding a growing older 'precariat'. Table 1 also shows that most of the self-employed were also long-established in their jobs (see also Parker and Rougier 2007), which suggests that self-employment is not masking involuntary insecure work for the most part.

FIGURE 1 HERE 


\section{Integration into full-time work}

Hypothesis 2 predicted that employees over 65 were becoming more integrated into full-time work, as continuing in a (full-time) job becomes more 'automatic' and less subject to discussion/negotiation. Consistent with increased integration into full-time jobs, Table 2 shows that the share of in part-time jobs fell from $72.7 \%$ in 2001 to $65.5 \%$ in 2014 . The decline in part-time employment was only evident for men, however. This is likely to reflect the dominance of part-time work among women before age 65. The LFS asks retirees that had worked in the previous eight years about their last job in relation to occupation, sector, working hours and workplace size. As can be seen from Table 2, more than half of female retirees had previously had part-time jobs.

While there was an overall increase in full-time employment, as predicted, it should be recognised that part-time work was the 'norm' for workers in all time periods. There was also little evidence of involuntary marginalisation into part-time work: $95-96 \%$ of part-time employees in each year said they did not want full-time work. Research elsewhere suggests that working beyond age 65 typically involves a reduction in working hours even if they remain with the same employer (Lain, forthcoming), a point that we return to in the conclusion when discussing the implications for management.

\section{Occupational and sectoral segregation}

\section{TABLE 3 HERE}

Hypothesis 3 predicted that employees over age 65 were becoming less marginalised in a narrow range of occupations and sectors. In order to test this, Table 3 compares the jobs held by employees aged 65-69 with the previous jobs held retirees of this age that had worked in the last eight years. Table 3 shows that employees remained over-represented in Lopaq jobs between 2001 and 2014, relative to the former jobs held by retirees. However, consistent with a reduced occupational marginalisation, this over-representation appears to be declining. In 2001 employees were 1.3 times more likely to be in Lopaq jobs, relative to the former jobs of retirees (44\% versus $32.7 \%$ ). By 2014 , employees were only 1.1 times more likely to be in Lopaq jobs than retirees (32.2\% versus $28 \%$ ). We examine whether this decline was statistically significant in the pooled regression analysis below. Craft workers were also under-represented in each time period. Finally, there was a rise in the proportion of employees in upper-level managerial, professional and associate professional roles, from $24 \%$ in 2001 to $33.8 \%$ in 2013 . This is likely to be a cohort effect, however, as the proportions in these roles mirrored that of retirees' former jobs. 
Sectoral concentrations of employees over 65s also declined over the period. In 2001 employees aged 65-69 were 1.6 times more likely to be working in retail/hotel/restaurants than retirees were in their former jobs; these are sectors with high numbers of Lopaq-like jobs (Lain, 2009). By 2014 employees were only 1.2 times more likely to be in retail etc. jobs than retirees. A significant underrepresentation in public administration and defence, which was present in 2001 and 2008, was also gone by 2014. This marks an important change, because as these typically public sector jobs often had 'normal' retirement ages of 60 and exit organised around final salary pensions (Mein et al., 2000). This suggests that pension arrangements cannot completely constrain the potential increased integration of workers over age 65 (see the discussion above).

\section{Regression analysis}

While the above results suggest that over $65 \mathrm{~s}$ are more integrated into work-organisations, logistic regression analysis is also presented to disentangle the effects of the different factors examined (Table 4). The dependent variable is whether someone aged 65-69 is an employee (a value of 1) or a retiree who worked in the last eight years (a value of zero). Independent variables that seek to predict employment are occupation, sector, workplace size, sex. (Model 1), and, added in Model 2, full-time/part-time status.

This regression analysis largely confirms the results of the previous analysis. In 2001 and 2008 (Model 1) we see that, controlling for the other factors, Lopaq employees were significantly overrepresented compared to all other occupations except clerks (in 2001) and operatives (in 2008). By 2014 this over-representation of employees in Lopaq occupations was gone, relative to all occupational groups except craft workers. The regression analysis also suggests that an overconcentration in particular sectors declined over the period. In 2001 five sectors had disproportionately high or low concentrations of employees aged 65-69, falling to three sectors in 2014. A statistically significant over-representation in retail, and an under-representation in public administration, disappeared by 2014. After controlling for sector, being in a larger employer reduced the likelihood of working at 65-69 in all years. However, the changing odds ratios over time suggest that this concentration in small employers may have declined to a degree - something we examine in the pooled regression. Women's relative likelihood of working was lower than men's across all the waves.

Model 2 includes part-time work, which is shown to be highly significant in increasing the likelihood of being a worker rather than a retiree. The higher likelihood of working in a Lopaq job in 2001 also disappears once part-time work is controlled for, reflecting the part-time nature of many of these 
jobs. The odds ratios for sector are also no longer significant once part-time work is included in the 2014 regression. Introducing part-time/full time status in Model 2 increases the amount of variation explained according to the Nagelkerke R $2 \mathrm{~s}$. However, the odds ratios for part-time work are extremely large in their own right: 7.52 in 2001, 5.44 in 2008, and 3.95 in 2014. These are likely to be inflated because we could not control for a range of other factors that might make part-timers more likely to work (including, for example, a lower likelihood of having a defined benefit pension). Nevertheless, the analysis suggests that the ability to work part-time was important in influencing whether someone stayed in employment, although the importance of this may be declining.

TABLE 5 here

A pooled regression (Table 5: Models 1-7) was conducted in order to determine whether the changes over time identified in earlier analysis were statistically significant, once we account for structural changes to sectoral and occupational distributions. All models include gender as a control variable and each includes interaction terms for selected variables by year. Model 1 includes the year and a variable aggregated into Lopaq/non-Lopaq occupations. This analysis confirms that the likelihood of working was significantly higher in the later years of 2008/2014, compared with 2001. Furthermore, Lopaq employment significantly increased the likelihood of being an employee rather than a retiree. Model 2 includes an interaction term for occupation and year. This confirms that, relative to 2001, having a Lopaq job was a less important influence on working in 2014 (note the significant odds ratio of 0.75 ). This is consistent with what we would expect, given a shift away from a concentration in Lopaq occupations.

Model 3 introduces sector, and the results mirror previous analysis in showing that individuals had an increased the likelihood of working if they were in retail, financial services, or other services. Model 4 introduces workplace size, and shows that the likelihood of working was significantly higher for those in the smallest workplace category of 10 or less staff. However, when an interaction term for workplace size and year is introduced in Model 5 we see that the relative likelihood of being employed in the workplace of 50+ staff was higher in 2008 and 2014 than in 2001. This is consistent with increased employment in large organisations.

In Model 6 we introduce the part-time/full-time variable; as expected, part-time jobs were significantly associated with being in being an employee rather than retiree. In model 7 an interaction term is introduced for year and part-time employment status. The interaction term for being part-time in 2014 is significant and below 1; this suggests that being in a part-time job was a less important influence on whether someone worked in 2014 (relative to 2001). This is consistent 
with a significant increase in the proportion of over 65s in full-time jobs between 2001 and 2014. Taken as a whole, the results suggest a significant move away from a concentration in Lopaq jobs, narrow sectors of employment, small workplaces and, to some degree, part-time work. It therefore provides supplementary evidence for the increased integration of over $65 \mathrm{~s}$ into organisations as employees; we consider the HR implications of these important changes in the concluding discussion.

\section{Discussion and HR/management implications}

This analysis provides evidence that since the start of the 21st Century, employment of the over-65s in the UK has moved gradually from the margins to the mainstream. The proportion working at age 65-69 almost doubled between 2001 and 2014, despite this time including the most severe recession of the post-war period. Moreover, refuting concerns over possible increases in precarity, the findings show that the rises reflected the increase in people continuing in jobs held for over ten years or more. The proportion of employees on temporary contracts likewise declined and full time employment increased. Part-time work remained the norm for most workers over 65 , but there was very little evidence of involuntary marginalisation into these jobs. Furthermore, a disproportionate concentration in lower-level 'Lopaq' occupations present in earlier years had also reduced. Finally, by 2014 over-65s were no longer under-represented in sectors such as public administration where retirement had been previously highly regulated, and there was also evidence of increasing integration into larger organisations. Regression analysis provides evidence that the move towards larger employers, 'non-Lopaq' jobs and (to some degree) full-time employment between 2001 and 2014 was statistically significant.

It is important not to over-state the case: only a minority currently work beyond 65 , and there remain important issues regarding employment practices to help retain workers below 65 or state pension age (Wood et al, 2008). There is also a need for public policies to help facilitate continued employment, including investments in life-long learning, a recognition of health limitations among many older people, and a tightening up of age discrimination legislation (see Lain, Forthcoming). Nevertheless increased employment beyond 65 , and the fact that there is now no clear fixed endpoint to employment, shifts the management of older workers and later life working to a core component of managerial practice. Increases in employment continuity indicate that challenges are likely to relate to managing long-term employees when there are few age-based markers for how long they will be there. Reflecting long-standing theoretical debates within the academic HR community, an overarching question is whether these challenges are best met through 
mainstreaming age management via generic HR policies and practices or are better tackled through age-contingent initiatives.

While there is some intuitive sense in adopting generic approaches, not least they are less likely to fall foul of the UK regulations which prohibit discrimination on grounds of age (CIPD, 2011), a growing body of work argues that as employees' needs (Kooij et al, 2010; 2011) and motives (Kooij et al, $2008 ; 2011 ; 2013 ; 2014)$ change with age so do the utility of specific HR practices. Much of this work draws on meta-analysis to show that with age, intrinsic aspects of work become more important as a motivator (also supported by Inceoglu et al, 2011), and relationships between HR practices and job satisfaction, commitment and job-related well-being change as a consequence. For example, Kooij et al's (2013) study in the UK public sector indicated that as employees age the importance of development practices (e.g. training) on job-related well-being weakens, while the importance of maintenance HR practices (such as performance appraisal) on well-being becomes stronger. They interpreted this as a shift away from growth-related work motives towards greater concern over maintaining current levels of functioning. However, such findings should not be used to deny training and development to older people; the same study found development practices became more important for increasing self-rated performance as people age. Care also needs to be taken in interpreting these findings as the study was cross-sectional, and cannot therefore distinguish between age and cohort effects.

In addition, the theories which have underpinned age-contingent approaches can be criticised for promoting a notion of ageing as decline. Such criticism has been empirically supported by Herrbach et al's (2009) work with French managers which argues against age-contingent HR practices, finding that older workers 'do not want to be treated according to their presumptive unique needs (p907), arguing that to do so risks reinforce negative age stereotypes, most of which lack empirical support(Ng and Feldman, 2008). Much of the practice-oriented literature (McNair et al., 2012) has worked hard to debunk negative stereotypes associated with older workers, thereby supporting a generic perspective to mainstreaming age management. A further perspective highlights the heterogeneity of older workers, arguing that people become more diverse in their abilities and orientations towards work as they grow older (see e.g. Flynn, 2010; Barnes-Farrell and Matthews, 2007). This perspective also recognises and that decisions around later-life working and when and how to retire are heavily influenced by a whole host of factors outside of the immediate work environment (Vickerstaff et al 2008; Loretto and Vickerstaff, 2013). Work in the Netherlands has highlighted the importance of individually-negotiated or idiosyncratic deals (I-deals) in motivating (older) employees to continue working (Bal et al, 2012). I-deals involving flexible working were 
viewed as more motivating than those offering opportunities for training or career development, (Bal et al, 2012: 314). In practice, the extent to which employees are empowered to negotiate individual deals is likely to vary enormously, with many lacking the knowledge or opportunity or confidence to do so (Vickerstaff et al, 2008). Furthermore, entering into I-deals would put more pressure onto line managers, who already feel under pressure when it comes to dealing with older workers (Leisink and Knies, 2011). On the other hand, they offer an opportunity for employers and managers to regain some control over retirement decisions, something they feel to have lost in recent years (Beck, 2013).

The findings reported in this article also point to some specific challenges whatever paradigm is adopted. The first of these relates to the organisation of working time. Existing research has identified demand for part-time work from older employees, arising from a desire for better worklife balance, to accommodate caring responsibilities, and to provide a more gradual transition from fulltime work to full-time retirement (Vickerstaff et al, 2008), but that options to work part-time are often not available (Vickerstaff, 2007). Our findings show that, while the majority of employees over65 work part-time, the relative prevalence of part-time work for men has declined in the past 12 years. This calls into question whether there is unmet demand for part-time working. Aside from our previous point relating to lack of employee knowledge and empowerment to request part-time working, managing a reluctant full-timer may perpetuate stereotypical views about the abilities and motivations of older workers, and result in HR techniques of e.g. performance management being used to 'manage out' older workers (Beck, 2013).

Following on from the previous point about performance management, in the context of increasing employment beyond age 65, 'managing an ageing workforce requires robust appraisal or development review systems' (CIPD 2011: 23). It is important that fair and objective criteria are used to monitor performance, rather than making decisions on the basis of crude stereotypes about the expected performance of older workers (CIPD 2011). Employers may now get into legal difficulties if they retire off staff seen as under-performing without evidence of their work-levels. On the other hand, appraisals are likely to be most effective when older workers feel valued, invested in and consulted about their needs and wishes. This is likely to benefit from a degree of honest conversation between both parties, which line managers in particular might be wary of because they do not want to contravene discrimination legislation. It is therefore important that line-mangers are given the skills, confidence and language to conduct appraisals and performance reviews that discuss employees' future plans and wishes without creating the perception that they are illegally coercing older people into retirement. An understanding of older workers plans/wishes can 
potentially aid succession planning and knowledge transfer. Likewise, opportunities such as mentoring younger colleagues or adapting work-based tasks can be discussed at appraisal, and these can potentially help retain older workers and maximise their contribution (Armstrong-Stassen and Schlosser, 2011: 322).

This shifting context suggests that future research will need to examine possible changes to employee relations and the employment relationship. Historically mandatory retirement spread with the agreement of Trade Unions in exchange for the provision of occupational pensions (Hannah, 1986). Research following age discrimination legislation in New Zealand, on the other hand, suggests that Trade Unions now have a potentially important role to play in enforcing age-based employment rights (Harcourt, 2004). In relation to occupational pensions, working past age 65 now raises the likelihood that many employees will wish to take their pension whilst continuing to work for the same company, perhaps in a part-time capacity (Lain and Vickerstaff, 2015). As this becomes more common more research will be needed on how this is managed.

An additional challenge arises from the fact that, despite increased employment past 65 , many people will still opt to retire at 65 or younger, and managing their trajectories to retirement will be rather different to sustaining longer-term working relationships. For individual line managers, the increase in perceived employee choice over continued working is likely to bring challenges of balancing individual work preferences and expectations with organisational needs. As such, the mainstreaming of over-65s is likely to intensify the often contradictory position HR practitioners and line managers find themselves in (Coupland et al, 2008), simultaneously trying to develop long-term mutually beneficial employment relationships but also dealing with pragmatic issues of manpower and succession planning. More research is therefore needed on the activities and experiences of those managing these workers.

This article has mapped the changes occurring with regard to workers over 65 , and has considered some of the management implications. The findings may have resonance beyond the UK, both for other countries recently abolishing mandatory retirement (New Zealand, Canada and Australia; see Wood et al 2010), or for employers from other countries that have voluntarily shed fixed retirement ages. It is important that future research improves understanding of the diverse experiences and motivations of this growing workforce, so that the 'fit' between employer offerings and individuals' preferences can be better met. This means future research on the older workforce should include 
people beyond the age of 65 . It also requires longitudinal research, to separate out age from cohort effects and understand changes over time as people age. Such changes of interest include the way in which job-tasks can alter in later life. For example, this 'new' workforce has the potential to make valuable contributions through mentoring or knowledge transfer, but this remains an underresearched area. Further research is needed on the implications of people working past 65 for performance management systems, for succession planning and mentoring, for the administration of occupational pensions, and for employee relations.

Managing older workers will become increasingly complex as we live and work longer, and as workforces become more age-diverse (CIPD, 2014). It will therefore become an increasingly important function of management, and we will perhaps know that it has truly moved from the margins to the mainstream when HR and management texts and guides routinely contain a chapter on age management.

\section{References}

Adams, S.J. (2004) 'Age discrimination legislation and the employment of older workers', Labour Economics, 11(2): 219-41.

Armstrong-Stassen, M. (2008) 'Organisational practices and the post-retirement employment experience of older workers', Human Resource Management Journal, 18(1): 36-53.

Bal, P.M., De Jong, S.B., Jansen, P.G.W. and Bakker, A.B. (2012) 'Motivating employees to work beyond retirement: A multi-level study of the role of $\mathrm{i}$-deals and unit climate', Journal of Management Studies, 49(2): 306-31.

Barnes-Farrell, J.L. and Matthews, R. (2007) 'Age and work attitudes', in K. Shultz and G. Adams (eds), Aging and work in the 21st century, Mahwah: LEA Laurence Erlbaum Associates., pp 139-62.

Beck, V. (2013) 'Employers' use of older workers in the recession', Employee Relations, 35(3): 257-71.

Bidewell, J., Griffin, B. and Hesketh, B. (2006) 'Timing of retirement: Including a delay discounting perspective in retirement models', Journal of Vocational Behavior, 68(2): 368-87.

CBI (2013) On the up: CBI/Accenture employment trends survey 2013, London: Conferation of British Industry.

CIPD (2011) Managing age: 2011 edition, Chartered Institute of Personnel and Development: London.

CIPD (2014) Managing an age-diverse workforce: Employer and employee views, Chartered Institute of Personnel and Development: London.

Coleman, L. (2011) Working life tracker: Wave 1 report, Department for Work and Pensions: London.

Coupland, C., Tempest, S. and Barnatt, C. (2008) 'What are the implications of the new UK age discrimination legislation for research and practice?', Human Resource Management Journal, 18(4): 423-31.

Crompton, R. (2001) 'Gender restructuring, employment, and caring', Social Politics: International Studies in Gender, State \& Society, 8(3): 266-91.

Flynn, M. (2010) 'The United Kingdom government's 'business case' approach to the regulation of retirement', Ageing \& Society, 30: 421-43. 
Friedberg, L. and Webb, A. (2005) 'Retirement and the evolution of pension structure', Journal of Human Resources, 40(2): 281-308.

Hannah, L. (1986) Inventing retirement: The development of occupational pensions in Britain, Cambridge: Cambridge University Press.

Harcourt, M., Wood, G. and Harcourt, S. (2004) 'Do unions affect employer compliance with the law? New Zealand evidence for age discrimination', British Journal of Industrial Relations, 42(3): 527-41.

Herrbach, O., Mignonac, K., Vandenberghe, C. and Negrini, A. (2009) 'Perceived HRM practices, organizational commitment, and voluntary early retirement among late-career managers', Human Resource Management, 48(6): 895-915.

Inceoglu, I., Segers, J. and Bartram, D. (2011) 'Age-related differences in work motivation', Journal of Occupational and Organizational Psychology, 85(2): 300-29.

Kooij, D., de Lange, A. and Dikkers, J. (2008) 'Older workers' motivation to continue to work: Five meanings of age: A conceptual review', Journal of managerial psychology, 23(4): 364-94.

Kooij, D.T., Jansen, P.G., Dikkers, J.S. and De Lange, A.H. (2010) 'The influence of age on the associations between $\mathrm{hr}$ practices and both affective commitment and job satisfaction: $\mathrm{A}$ meta-analysis', Journal of Organizational Behavior, 31(8): 1111-36.

Kooij, D.T., De Lange, A.H., Jansen, P.G., Kanfer, R. and Dikkers, J.S. (2011) 'Age and work-related motives: Results of a meta-analysis', Journal of Organizational Behavior, 32(2): 197-225.

Kooij, D.T., Guest, D.E., Clinton, M., Knight, T., Jansen, P.G. and Dikkers, J.S. (2013) 'How the impact of HR practices on employee well-being and performance changes with age', Human Resource Management Journal, 23(1): 18-35.

Kooij, D.T., Jansen, P.G., Dikkers, J.S. and de Lange, A.H. (2014) 'Managing aging workers: A mixed methods study on bundles of hr practices for aging workers', The International Journal of Human Resource Management, 25(15): 2192-212.

Lain, D. (2009) Healthy, wealthy and wise? Working past age 65 in the uk and USA, Sociology DPhil, Brighton: University of Sussex.

Lain, D. (2011) 'Helping the poorest help themselves? Encouraging employment past 65 in England and the USA', Journal of Social Policy, 40: 493-512.

Lain, D. (2012a) 'Comparing health and employment in england and the united states', in S. Vickerstaff, C. Phillipson and R. Wilkie (eds), Work, health and well-being: The challenges of managing health at work, Bristol: The Policy Press, pp 59-78.

Lain, D. (2012b) 'Working past 65 in the UK and the USA: Segregation into 'Lopaq' occupations?', Work, Employment \& Society, 26(1): 78-94.

Lain, D. and Vickerstaff, S. (2015) National report: United Kingdom, Berlin: Federal Ministry of Labour and Social Affairs (BMAS) and Federal Institute for Occupational Safety and Health (BAuA).

Lain, D. (forthcoming) The reconstruction of retirement: Work and welfare in the UK and USA, Bristol: Policy Press.

Leisink, P.L.M. and Knies, E. (2011) 'Line managers' support for older workers', International Journal of Human Resource Management, 22(9): 1902-17.

Loretto, W. and White, P. (2006) 'Employers' attitudes, practices and policies towards older workers', Human Resource Management Journal, 16(3): 313-30.

Loretto, W. and Vickerstaff, S. (2013) 'The domestic and gendered context for retirement', Human Relations, 66(1): 65-86.

Macnicol, J. (2006) Age discrimination: An historical and contemporary analysis, Cambridge: Cambridge University Press.

McMunn, A., Nazroo, J., Wahrendorf, M., Breeze, E. and Zaninotto, P. (2009) 'Participation in socially-productive activities, reciprocity and wellbeing in later life: Baseline results in england', Ageing \& Society, 29: 765-82.

McNair, S., Flynn, M., Worman, D. and Wilmott, B. (2012) Managing a healthy ageing workforce: A national business imperative, London: Chartered Institute of Personnel and Development. 
Metcalf, H. and Meadows, P. (2006) Survey of employers' policies, practices and preferences relating to age, London: Department for Work and Pensions.

Munnell, A.H., Triest, R.K. and Jivan, N.A. (2004) How do pensions affect expected and actual retirement ages, Chestnut Hill, MA: Center for Retirement Research at Boston College.

Ng, T.W. and Feldman, D.C. (2008) 'The relationship of age to ten dimensions of job performance', Journal of Applied Psychology, 93(2): 392.

ONS (2013) Labour market statistics, June 2013, London: Office for National Statistics.

Parker, S.C. and Rougier, J.C. (2007) 'The retirement behaviour of the self-employed in Britain', Applied Economics, 39(4-6): 697-713.

Parry, E. and Tyson, S. (2009) 'Organizational reactions to uk age discrimination legislation', Employee Relations, 31(5): 471-88.

Parry, J. and Taylor, R. (2007) 'Orientation, opportunity and autonomy: Why people work after state pension age in three areas of England', Ageing \& Society, 27(04): 579-98.

Phillipson, C. (1982) Capitalism and the construction of old age, London: Macmillan.

Riach, K. (2011) 'Situating age (in)equality within the paradigm and practises of diversity management', in E. Parry and S. Tyson (eds), Managing an age diverse workforce, Basingstoke: Palgrave Macmillan, pp 43-58.

Shultz, K.S., Morton, K.R. and Weckerle, J.R. (1998) 'The influence of push and pull factors on voluntary and involuntary early retirees' retirement decision and adjustment', Journal of Vocational Behavior, 53(1): 45-57.

Smeaton, D. and McKay, S. (2003) Working after state pension age: Quantitative analysis, Leeds: Department for Work and Pensions.

Standing, G. (2011) The precariat: The dangerous new class, London: Bloomsbury Academic.

Taylor, P.E. and Walker, A. (1994) 'The ageing workforce: Employers' attitudes towards older people', Work, Employment \& Society, 8(4): 569-91.

Vickerstaff, S. (2006) 'Entering the retirement zone: How much choice do individuals have?', Social Policy and Society, 5(04): 507-17.

Vickerstaff, S. (2007) 'What do older workers want? Gradual retirement?', Social \& Public Policy Review, 1(1).

Vickerstaff, S., Loretto, W., Billings, J., Brown, P., Mitton, L., Parkin, T., White, P. and Britain, G. (2008) Encouraging labour market activity among 60-64 year olds, Norwich.

Wood, A., Robertson, M. and Wintersgill, D. (2010) A comparative review of international approaches to mandatory retirement, Norwich: H. M. s. S. Office.

Wood, G., Wilkinson, A. and Harcourt, M. (2008) 'Age discrimination and working life: Perspectives and contestations - a review of the contemporary literature', International Journal of Management Reviews, 10(4): 425-42. 
Table 1: Employment of those aged 65-69

$\begin{array}{lll}2001 \text { (a) } & 2008(b) & 2014(c) \\ \text { (After the 2006 right } & \text { (After the 2011 } \\ \text { to request 65+ } & \text { abolition of } \\ \text { employment) } & \text { mandatory } \\ & \text { retirement) }\end{array}$

Men and Women

\begin{tabular}{|c|c|c|c|}
\hline Employee & $7.5^{* \mathrm{bc}}$ & $11.3^{* a c}$ & $13.3 * \mathrm{ab}$ \\
\hline Self-employed & $3.8 * \mathrm{bc}$ & $5.0 * \mathrm{ac}$ & $6.9 * a b$ \\
\hline Total \% working & $11.2^{* \mathrm{bc}}$ & $16.3^{* a c}$ & $20.2^{* a b}$ \\
\hline Base (including non-workers) & 6506 & 5959 & 6524 \\
\hline \multicolumn{4}{|l|}{ Men working } \\
\hline Employee & $8.2 * b c$ & $13.0 * a$ & $14.4^{* a}$ \\
\hline Self-employed & $6.3 * \mathrm{bc}$ & $8.1^{* a c}$ & $10.1 * a b$ \\
\hline Total \% working & $14.5^{* \mathrm{bc}}$ & $21.2^{* a c}$ & $24.4^{* a b}$ \\
\hline Base (including non-workers) & 3140 & 2825 & 3156 \\
\hline \multicolumn{4}{|l|}{ Women working } \\
\hline Employee & $6.8^{* \mathrm{bc}}$ & $9.7^{* \mathrm{ac}}$ & $12.3^{\mathrm{ab}}$ \\
\hline Self-employed & $1.5^{* \mathrm{bc}}$ & $2.1 * \mathrm{ac}$ & $4.0^{\mathrm{ab}}$ \\
\hline Total \% working & $8.3^{* \mathrm{bc}}$ & $11.7 * a c$ & $16.3^{\mathrm{ab}}$ \\
\hline Base (including non-workers) & 3366 & 3134 & 3368 \\
\hline \multicolumn{4}{|l|}{$\begin{array}{l}\text { Employees - Length current } \\
\text { employment }\end{array}$} \\
\hline Under 2 years & $22.8^{* b c}$ & $13.4^{* a}$ & $11.9 * a$ \\
\hline $2-5$ years & $22.4^{* c}$ & $17.5^{* c}$ & $11.1^{* a}$ \\
\hline $5-10$ years & $16.0 * b$ & $21.8^{* a}$ & 18.0 \\
\hline $10-20$ years & $17.3^{* \mathrm{bc}}$ & $24.8 * a$ & $28.1 * a$ \\
\hline $20+$ years & $21.5^{* c}$ & $22.6 * c$ & $30.9 * a b$ \\
\hline Total Column \% & 100 & 100 & 100 \\
\hline Base & 477 & 655 & 861 \\
\hline $\begin{array}{l}\text { Temporary employment for } \\
\text { employees }\end{array}$ & $18.0^{* b c}$ & $12.2^{* a}$ & $11.5^{* a}$ \\
\hline \multicolumn{4}{|l|}{$\begin{array}{l}\text { Self-Employed - Length of } \\
\text { employment }\end{array}$} \\
\hline Under 5 years & $19.0 * c$ & $19.2^{* c}$ & $11.9 * a b$ \\
\hline $5-10$ years & 14.1 & 10.5 & 9.7 \\
\hline $10-20$ years & 21.8 & 24.1 & 24.6 \\
\hline $20+$ years & 45.1 & 46.2 & 53.8 \\
\hline
\end{tabular}




\begin{tabular}{|l|l|l|l|}
\hline Total Column \% & 100.0 & 100.0 & 100.0 \\
\hline Base & 244 & 291 & 454 \\
\hline
\end{tabular}

Source: Analysis of the July-September LFS 2001, 2008 and 2014

Note $=^{*}=$ difference significant at the $p<0.05$ (the letter indicates the column(s) it is different from)

Table 2: Part-time rates and preferences for individuals aged 65-69

\begin{tabular}{|c|c|c|c|c|c|c|}
\hline & \multicolumn{2}{|c|}{2001} & \multicolumn{2}{|c|}{2008} & \multicolumn{2}{|c|}{2014} \\
\hline & Employee & Retiree & Employee & Retiree & Employee & Retiree \\
\hline Part-time rates & & & & & & \\
\hline Men and Women & $72.7^{*}$ & 32.2 & $69.9^{*}$ & 35.6 & $65.5^{*}$ & 37.3 \\
\hline Men & $62.5^{*}$ & $11.3^{*}$ & $59.2^{*}$ & 16.4 & $49.6^{*}$ & 18.4 \\
\hline Women & $83.8^{*}$ & 56.6 & $83.3^{*}$ & 56.1 & $83.0^{*}$ & 55.4 \\
\hline $\begin{array}{l}\text { Preferences of } \\
\text { Part-timers }\end{array}$ & & & & & & \\
\hline $\begin{array}{l}\text { Part-timers not } \\
\text { wanting full-time }\end{array}$ & 94.8 & & 96.4 & & 95.4 & \\
\hline Base & 476 & 2518 & 659 & 2146 & 863 & 2656 \\
\hline
\end{tabular}

Note: ${ }^{*}=$ a significant difference from retirees at the $p<0.05$ level.

Source: Analysis of the July-September LFS 2001, 2008 and 2014 
Table 3: The occupation, sector and workplace size of employees and retirees aged 65-69

\begin{tabular}{|c|c|c|c|c|c|c|}
\hline \multirow{2}{*}{ Occupation } & \multicolumn{2}{|c|}{2001} & \multicolumn{2}{|c|}{2008} & \multicolumn{2}{|c|}{2014} \\
\hline & Employee & Retiree & Employee & Retiree & Employee & Retiree \\
\hline $\begin{array}{l}\text { Managers / Profs / Assoc } \\
\text { Prof }\end{array}$ & 24.0 & 26.8 & 30.4 & 30.6 & 33.8 & 33.6 \\
\hline Crafts & $7.5^{\star}$ & 11.9 & $5.8^{\star}$ & 9.6 & $7.6^{\star}$ & 10.1 \\
\hline Operatives & $8.3^{*}$ & 12.4 & 12.0 & 13.4 & 8.9 & 9.4 \\
\hline Clerks & 16.2 & 16.2 & $13.1^{*}$ & 16.3 & 17.4 & 18.8 \\
\hline Lopaq Occupations & $44.0^{\star}$ & 32.7 & $38.7^{\star}$ & 30.2 & $32.2^{*}$ & 28.0 \\
\hline Total Column \% & $100.0 \%$ & $100.0 \%$ & $100.0 \%$ & $100.0 \%$ & $100.0 \%$ & $100.0 \%$ \\
\hline \multicolumn{7}{|l|}{ Sector } \\
\hline Manufacturing & $17.0^{*}$ & 25.1 & $10.8^{\star}$ & 19.8 & $9.6^{*}$ & 14.5 \\
\hline Other goods production & $5.7^{*}$ & 8.5 & 7.0 & 7.6 & $5.9^{*}$ & 9.0 \\
\hline $\begin{array}{l}\text { Retail, hotels, restaurants } \\
\text { etc }\end{array}$ & $24.4^{*}$ & 16.2 & $21.7^{\star}$ & 16.1 & $17.4^{*}$ & 14.4 \\
\hline $\begin{array}{l}\text { Transport \& } \\
\text { communication }\end{array}$ & 4.2 & 6.5 & 7.3 & 7.4 & 6.0 & 6.6 \\
\hline $\begin{array}{l}\text { Financial / Business } \\
\text { Services }\end{array}$ & $13.7^{\star}$ & 8.1 & $13.1^{*}$ & 9.2 & $18.6^{*}$ & 11.8 \\
\hline $\begin{array}{l}\text { Public administration \& } \\
\text { defence }\end{array}$ & $5.0^{*}$ & 8.0 & $4.9^{*}$ & 8.1 & 6.3 & 7.6 \\
\hline Education & 9.0 & 10.7 & 11.4 & 12.3 & 11.6 & 14.2 \\
\hline Health \& social work & 11.8 & 12.2 & 15.9 & 13.8 & 16.9 & 16.7 \\
\hline Other services & 9.2 & $4.6^{*}$ & $8.0^{*}$ & 5.7 & $7.7^{\star}$ & 5.1 \\
\hline Total Column \% & $100.0 \%$ & $100.0 \%$ & $100.0 \%$ & $100.0 \%$ & $100.0 \%$ & $100.0 \%$ \\
\hline Private sector & 78.8 & & 75.1 & & 72.5 & \\
\hline Public sector & 21.2 & & 24.9 & & 27.5 & \\
\hline \multicolumn{7}{|l|}{ Workplace size } \\
\hline $1-10$ & $36.6^{*}$ & 18.8 & $30.1^{*}$ & 20.8 & $32.6^{*}$ & 19.6 \\
\hline $11-24$ & 17.5 & 14.1 & $19.9^{*}$ & 15.5 & 14.5 & 14.8 \\
\hline $25-49$ & 13.1 & 12.0 & 15.0 & 12.9 & 12.6 & 14.2 \\
\hline $50+$ & $32.8^{*}$ & 55.0 & $34.9^{*}$ & 50.8 & $40.3^{\star}$ & 51.4 \\
\hline Total Column \% & $100.0 \%$ & $100.0 \%$ & $100.0 \%$ & $100.0 \%$ & $100.0 \%$ & $100.0 \%$ \\
\hline Base & 476 & 2518 & 659 & 2146 & 863 & 2656 \\
\hline
\end{tabular}

* = a significant difference between employees and retirees (at the $p<0.05$ level).

Note: Retirees worked as employees in the last eight years. Occupation details relate to last job.

Source: Analysis of the July-September LFS 2001, 2008 and 2014 

Table 4: Work factors associated with working aged 65-69, by sex 2010 (odds ratios from logistic regression)

Model 1:

Excluding part-time work variable
Model 2:

Including part-time work variable

\begin{tabular}{|c|c|c|c|c|c|c|}
\hline & 2001 & 2008 & 2014 & 2001 & 2008 & 2014 \\
\hline \multicolumn{7}{|l|}{ Occupation } \\
\hline Lopaq occs (Ref) & 1.00 & 1.00 & 1.00 & 1.00 & 1.00 & 1.00 \\
\hline Managers etc & $0.75^{\star}$ & $0.82^{\circ}$ & 0.91 & 1.13 & 1.07 & 1.17 \\
\hline Crafts & $0.51^{* *}$ & $0.47^{\star \star \star}$ & $0.72^{\circ}$ & 0.77 & 0.73 & 0.95 \\
\hline Operatives & $0.62^{*}$ & 0.83 & 0.91 & 0.79 & 1.18 & 1.13 \\
\hline Clerks & 0.85 & $0.77^{\circ}$ & 0.87 & 0.96 & 0.83 & 0.95 \\
\hline \multicolumn{7}{|l|}{$\begin{array}{l}\text { Sector (contrast = } \\
\text { deviation) }\end{array}$} \\
\hline Manufacturing & 0.90 & $0.59^{\star \star \star}$ & $0.71^{\star \star}$ & 1.10 & $0.69^{* *}$ & 0.88 \\
\hline Retail etc & $1.28^{*}$ & $1.26^{*}$ & 1.17 & 1.13 & 1.18 & 1.04 \\
\hline Transport etc & $0.65^{\circ}$ & 0.87 & 0.89 & 0.74 & 0.95 & 0.98 \\
\hline Financial & $1.51^{\star \star}$ & 1.38 & $1.55^{\star \star \star}$ & $1.56^{\star *}$ & $1.45^{\star *}$ & 1.59 \\
\hline Public Admin & $0.68^{\circ}$ & $0.68^{*}$ & 0.92 & $0.67^{\circ}$ & 0.76 & 0.87 \\
\hline Education & 1.05 & 1.08 & 0.99 & 0.81 & 0.81 & 0.81 \\
\hline Health \& social work & 1.09 & $1.39^{\star \star}$ & 1.15 & 0.87 & 1.17 & 1.03 \\
\hline Other services & $1.57^{\star}$ & 1.26 & $1.30^{\circ}$ & $1.51^{*}$ & 1.12 & 1.33 \\
\hline \multicolumn{7}{|l|}{ Workplace Size } \\
\hline $1-10$ (Ref) & 1.00 & 1.00 & 1.00 & 1.00 & 1.00 & 1.00 \\
\hline $11-24$ & $0.74^{*}$ & 0.91 & $0.58^{\star \star \star}$ & 0.85 & 1.00 & 0.68 \\
\hline $25-49$ & $0.64^{\star \star}$ & 0.82 & $0.62^{\star \star *}$ & 0.78 & 1.05 & 0.73 \\
\hline $50+$ & $0.37^{\star \star \star}$ & $0.52^{* \star *}$ & $0.53^{\star \star \star}$ & $0.51^{\star \star \star}$ & $0.64^{\star \star \star}$ & 0.67 \\
\hline \multicolumn{7}{|l|}{ Sex (male = ref) } \\
\hline Male (ref) & 1.00 & 1.00 & 1.00 & 1.00 & 1.00 & 1.00 \\
\hline Female & $0.70^{\star \star}$ & $0.60^{* *}$ & $0.74^{\star *}$ & $0.38^{\star \star *}$ & $0.40^{\star \star \star}$ & 3.95 \\
\hline \multicolumn{7}{|l|}{ Hours of work } \\
\hline Full-time (ref) & & & & 1.00 & 1.00 & 1.00 \\
\hline Part-time & & & & $7.52^{\star \star \star}$ & $5.44^{\star \star \star}$ & 0.53 \\
\hline Constant & $0.47^{* \star \star}$ & $0.63^{* \star \star}$ & $0.61^{* \star \star}$ & $0.15^{\star \star \star}$ & $0.23^{\star \star \star}$ & 0.27 \\
\hline Nagelkerke R2 & 0.079 & 0.067 & 0.047 & 0.209 & 0.188 & 0.134 \\
\hline Base & 2972 & 2773 & 3489 & 2971 & 2773 & 3487 \\
\hline
\end{tabular}

Note: The sample is of employees and retirees who worked in the last eight years (giving info on their last job).

a: The deviation contrast was used as there was no obvious reference category. It compares each category with the overall effect of sector on employment (excluding goods production).

$* * *=p<0.001,{ }^{* *}=p<0.01,{ }^{*}=p<0.05,^{\circ}=p<0.10$

Source: Analysis of the July-September LFS 2001, 2008 and 2014 
Table 5: Work factors associated with working aged 65-69: Pooled analysis for 2001, 2008 and 2014 (odds ratios from logistic regression)

\begin{tabular}{|c|c|c|c|c|c|c|c|}
\hline & Model 1 & Model 2 & Model 3 & Model 4 & Model 5 & Model 6 & $\begin{array}{l}\text { Model } \\
7\end{array}$ \\
\hline Year (ref: 2001) & 1.00 & 1.00 & 1.00 & 1.00 & 1.00 & 1.00 & 1.00 \\
\hline 2008 Wave & $1.63^{\star \star \star}$ & $1.71^{\star \star \star}$ & $1.66^{\star \star \star}$ & $1.62^{\star \star \star}$ & $1.28^{\circ}$ & 1.25 & $1.47^{*}$ \\
\hline 2014 Wave & $1.74^{\star \star \star}$ & $1.93^{\star \star \star}$ & $1.80^{* \star \star}$ & $1.78^{\star \star \star}$ & $1.57^{\star \star}$ & $1.50^{\star \star}$ & $2.03^{\star \star \star}$ \\
\hline $\begin{array}{l}\text { Non-Lopaq occ } \\
\text { (ref) }\end{array}$ & 1.00 & 1.00 & 1.00 & 1.00 & 1.00 & 1.00 & 1.00 \\
\hline Lopaq Occupation & $1.46^{\star \star \star}$ & $1.70^{\star \star \star}$ & $1.48^{* \star *}$ & $1.42^{* \star}$ & $1.38^{* \star}$ & 1.07 & 0.99 \\
\hline Lopaq x 2008 & & 0.89 & 0.89 & 0.92 & 0.95 & 0.98 & 1.04 \\
\hline Lopaq x 2014 & & $0.75^{\star}$ & $0.77^{*}$ & $0.79^{\circ}$ & 0.83 & 0.85 & 0.95 \\
\hline Manufacturing & & & $0.62^{* \star \star}$ & $0.68^{* \star \star}$ & $0.69^{\star \star \star}$ & $0.84^{*}$ & $0.84^{\star}$ \\
\hline Retail etc & & & $1.34^{\star *}$ & $1.23^{\star \star}$ & $1.22^{\star \star}$ & 1.11 & 1.11 \\
\hline Transport etc & & & $0.82^{*}$ & $0.84^{\circ}$ & $0.85^{\circ}$ & 0.93 & 0.93 \\
\hline Financial & & & $1.62^{\star \star \star}$ & $1.52^{\star \star \star}$ & $1.52^{\star * \star}$ & $1.54^{* * *}$ & $1.53^{\star \star \star}$ \\
\hline Public Admin & & & $0.72^{\star \star}$ & $0.79^{\star}$ & $0.79^{\star}$ & $0.77^{\star}$ & $0.78^{*}$ \\
\hline Education & & & 0.93 & 1.06 & 1.05 & $0.85^{\star}$ & $0.85^{*}$ \\
\hline $\begin{array}{l}\text { Health \& social } \\
\text { work }\end{array}$ & & & $1.17^{*}$ & $1.20^{\star *}$ & $1.21^{* *}$ & 1.04 & 1.04 \\
\hline Other services & & & $1.58^{\star \star \star}$ & $1.35^{\star *}$ & $1.36^{* \star}$ & $1.30^{* *}$ & $1.29^{\star \star}$ \\
\hline \multicolumn{8}{|l|}{ Workplace Size } \\
\hline $1-10$ (Ref) & & & & 1.00 & 1.00 & 1.00 & 1.00 \\
\hline $11-24$ & & & & $0.72^{\star \star \star}$ & $0.72^{*}$ & 0.82 & 0.83 \\
\hline $25-49$ & & & & $0.69^{\star \star \star}$ & $0.62^{\star \star}$ & $0.74^{\circ}$ & 0.76 \\
\hline $50+$ & & & & $0.49^{\star \star \star}$ & $0.38^{\star \star \star}$ & $0.49^{* \star *}$ & $0.51^{\star \star \star}$ \\
\hline \multicolumn{8}{|l|}{ Work size $\mathrm{X}$ wave } \\
\hline $11-24$ x 2008 & & & & & 1.27 & 1.22 & 1.20 \\
\hline $11-24 \times 2014$ & & & & & 0.81 & 0.84 & 0.82 \\
\hline $25-49 \times 2008$ & & & & & 1.37 & $1.47^{\circ}$ & 1.44 \\
\hline $25-49 \times 2014$ & & & & & 1.01 & 1.02 & 0.98 \\
\hline $50+\times 2008$ & & & & & $1.41^{*}$ & 1.33 & 1.27 \\
\hline $50+x 2014$ & & & & & $1.42^{*}$ & $1.45^{*}$ & 1.33 \\
\hline Full-time (ref) & & & & & & 1.00 & 1.00 \\
\hline Part-time & & & & & & $5.05^{\star \star \star}$ & $6.74^{\star \star \star}$ \\
\hline Part-time x 2008 & & & & & & & 0.78 \\
\hline Part-time x 2014 & & & & & & & $0.62^{\star \star}$ \\
\hline & & & & & & & \\
\hline Male (ref) & 1.00 & 1.00 & 1.00 & 1.00 & 1.00 & 1.00 & 1.00 \\
\hline Female & $0.85^{* *}$ & $0.85^{* *}$ & $0.75^{\star \star \star}$ & $0.70^{\star \star \star}$ & $0.70^{\star \star \star}$ & $0.43^{* \star \star}$ & $0.43^{\star \star \star}$ \\
\hline
\end{tabular}




\begin{tabular}{|l|l|l|l|l|l|l|l|}
\hline Constant & $0.18^{\star * *}$ & $0.17^{* * *}$ & $0.19^{* \star *}$ & $0.30^{* * *}$ & $0.35^{\star * *}$ & $0.18^{\star * *}$ & $0.15^{* * *}$ \\
\hline & & & & & & & \\
\hline Nagelkerke R2 & 0.021 & 0.022 & 0.048 & 0.067 & 0.070 & 0.177 & 0.178 \\
\hline & & & & & & & \\
\hline Base & 9231 & 9231 & 9231 & 9231 & 9231 & 9231 & 9231 \\
\hline
\end{tabular}

$* * *=p<0.001,{ }^{* *}=p<0.01, *=p<0.05,^{\circ}=p<0.10$

a: The deviation contrast was used for sector as there was no obvious reference category. It compares each category with the overall effect of sector on employment (excluding goods production).

Source: Analysis of the July-September LFS 2001, 2008 and 2014 
Figure 1: Percentages working as employees at age 65-69 broken down by employment tenure

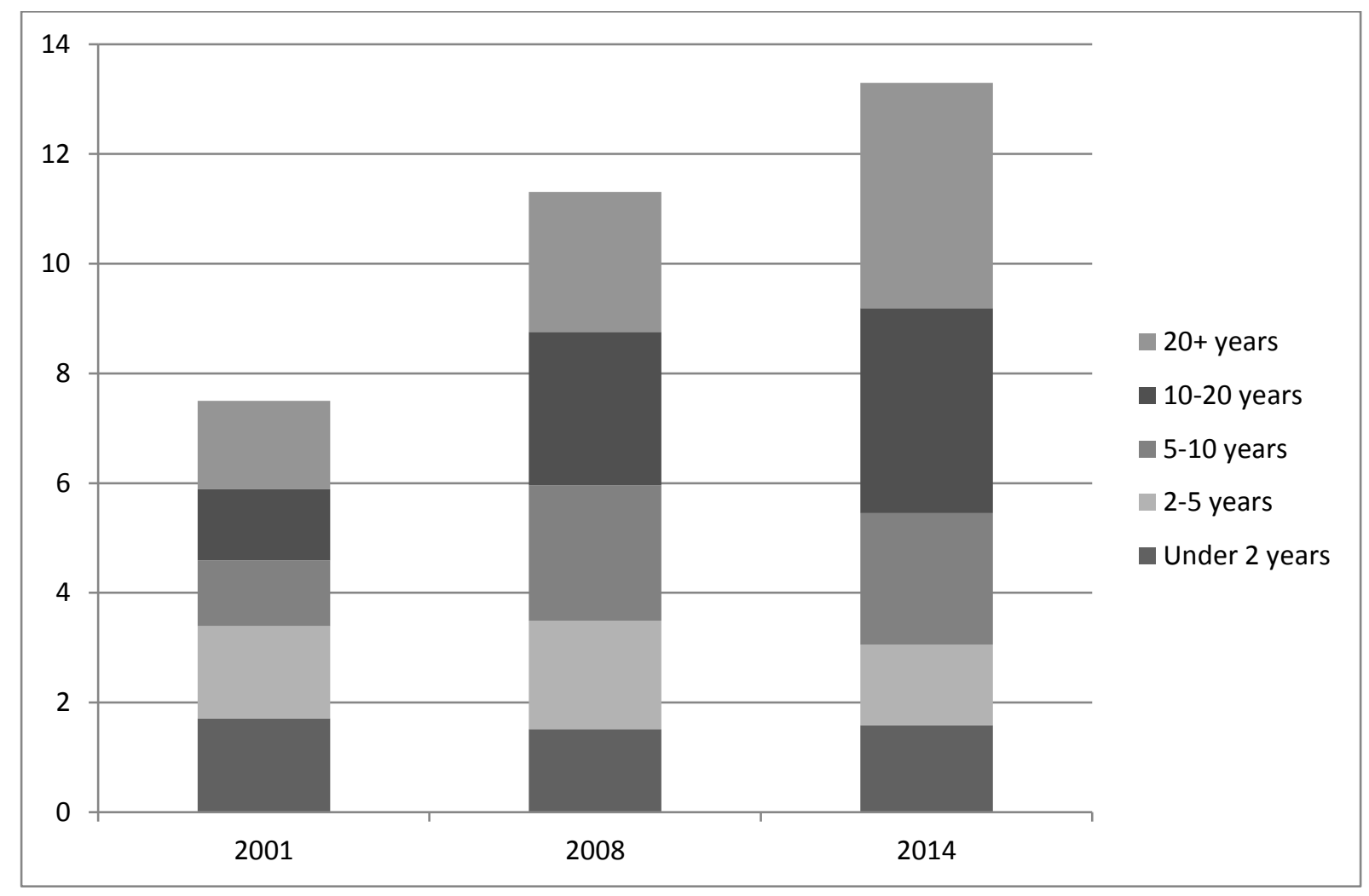

Source: Analysis of the July-September LFS 2001, 2008 and 2014 